www.scielo.br/rbg

\title{
ANÁLISE DA ACURÁCIA DAS ESTIMATIVAS DE POSICIONAMENTO DO NÍVEL FREÁTICO E DOS TEORES DE UMIDADE DO SOLO COM O EMPREGO DOS MÉTODOS DE SÍSMICA DE REFRAÇÃO RASA E GEORADAR A PARTIR DE UM ESTUDO NO CAMPUS DA USP, SÃO PAULO/SP
}

\author{
Manuelle Santos Góis Paixão \\ Orientador: Dr. Renato Luiz Prado (IAG-USP) \\ 117 p. - Dissertação (Mestrado) - Defesa 17.05.2005
}

\begin{abstract}
RESUMO. A pesquisa teve como objetivo integrar o método GPR (Ground Penetrating Radar) com a sísmica de refração, visando o mapeamento do N.A. e a estimativa do teor de umidade em uma área de estudos hidrogeológicos no campus da USP, assim como analisar a acurácia da medida dos dois métodos. Foram realizados ensaios geofísicos, granulométricos, de teor de umidade, do grau de saturação, do monitoramento do N.A. e acompanhamento dos índices pluviométricos em três períodos com variações sazonais no decorrer de um ano denominados período chuvoso (janeiro/2004); período intermediário (abril/2004) e período seco (setembro/2004). 0 mapeamento do N.A. com GPR foi feito com geometria multioffset, com as antenas de freqüências centrais $50 \mathrm{MHz}, 100 \mathrm{MHz}$ e $200 \mathrm{MHz}$, sendo que as antenas de $100 \mathrm{MHz}$ e $200 \mathrm{MHz}$ foram as que caracterizaram 0 N.A., refletindo sua variação sazonal e mantendo a tendência prof.N.A.janeiro $<$ prof.N.A.abril $<$ prof.N.A. setembro. 0 emprego da sísmica de refraçãa gerou maiores erros e ambigüidades na inversão dos dados. Neste estudo, a sísmica de refração não foi sensível às variações sazonais e, embora os resultados tenham se aproximado das observações diretas, não permitiram mapear a flutuação do N.A. entre os diferentes períodos. A estimativa do teor de umidade volumétrico pelo GPR foi obtida com duas metodologias diferentes que utilizaram a onda direta no solo. Foram empregadas antenas de $50 \mathrm{MHz}, 100 \mathrm{MHz}$ e $200 \mathrm{MHz}$ nos diferentes períodos. Observou-se uma variação da umidade entre os períodos, sendo o teor de umidade de janeiro > abril > setembro. A antena de $200 \mathrm{MHz}$ foi a que possibilitara uma melhor acurácia na estimativa do teor de umidade volumétrico.
\end{abstract}

ABSTRACT. The present study had as objective to integrate GPR (Ground Penetrating Radar) method to seismic refraction, focusing on water table mapping and on the estimate of water content in an area of hydrogeological studies at USP's campus, as well as analyzing the measuring accuracy of both methods. Several assays were accomplished, such as geophysical, granulometric, of water content, saturation degree, water table monitoring assays and also accompaniment of pluviometric indexes in the study periods with seasonal variations, along a year, denominated rainy period (january/2004), intermediary period (april/2004), and dry period (september/2004). Water table mapping by GPR was made with multi-offset geometry, with $50 \mathrm{MHz}$, $100 \mathrm{MHz}$ and $200 \mathrm{MHz}$ central frequency antennas, seeing that $100 \mathrm{MHz}$ and $200 \mathrm{MHz}$ antennas were those ones, which characterized the water table, reflecting its seasonal variation and maintaining the depth of the water table january $<$ depth $_{\text {april }}<$ depth $_{\text {september }}$ tendency. The use of seismic refraction generated larger mistakes and ambiguities in the data inversion. In this study, seismic refraction was not sensitive to seasonal variations and, although the results have approached to direct observations, they did not allow mapping the water table fluctuation among the different periods. The estimate of volumetric water content by GPR was obtained with two different methodologies that have used the direct ground wave. Fifty MHz, $100 \mathrm{MHz}$ and $200 \mathrm{MHz}$ antennas were used in the different periods. A moisture variation was observed among these periods, being the water content of January > April > September. Two hundred MHz antenna was the one that had facilitated a better accuracy in the estimate of moisture content. 